\title{
A REVIEW OF GROUND HEAT EXCHANGERS FOR COOLING APPLICATION IN THE MALAYSIAN CLIMATE
}

\author{
T.M. Yusof ${ }^{1,2, a}$, S. Anuar ${ }^{1, b}$ and H. Ibrahim ${ }^{1, c}$ \\ ${ }^{\mathbf{1}}$ Faculty of Mechanical Engineering, University Malaysia Pahang \\ 26600 Pekan, Pahang, Malaysia \\ Phone: +609-424-6257; Fax: +609-424-6200 \\ Email: ${ }^{a}$ myusof@ump.edu.my, ${ }^{b}$ shahrani@ump.edu.my, ${ }^{c}$ drhassan@ump.edu.my \\ ${ }^{2}$ Automotive Engineering Centre, Universiti Malaysia Pahang, \\ 26600 Pekan, Pahang, Malaysia
}

\begin{abstract}
The ground heat exchanger (GHE) is one of the energy sources that has been identified since the 1970s which is able to produce sustainable energy for cooling which is in passive side. GHEs are widely implemented around the world, especially in European countries and a few Asian countries. In Malaysia, application of GHE is still considered as a new passive cooling approach in building energy reduction. Therefore, this paper reviews several important ways of implementing GHE in order to supply passive cooling for any application. The review covers general implementation of the GHE for thermal comfort and agricultural greenhouse cooling. The ground temperature variation used in different researches is also reviewed in this paper as an important part of identifying potential GHE implementations. Design and performance aspects of the GHE are also reviewed. Finally, this paper summarizes the potential and benefit of GHE implementation in the Malaysian climate for cooling applications to reduce the energy used in buildings and greenhouse gas emission.
\end{abstract}

Keywords: Ground heat exchanger; space cooling; underground temperature variation; Malaysian climate.

\section{INTRODUCTION}

Diversification of energy sources for energy saving and reduction in greenhouse gas emission have been discussed since the 1990s as an alternative to fossil fuel. Solar energy is popular as it is high capability in terms of electricity generation and hot water production worldwide $[1,2]$. Wind with a certain velocity is able to rotate turbine propellants which then produce usable electricity and this source has also been explored widely. Currents of water flow in rivers and seas have also been utilized as an alternative to fossil fuel. Temperature fluctuation under the ground has been utilized in certain countries for passive use of thermal comfort. All these kinds of resources are able to reduce energy produced by fossil fuel and greenhouse gas emission. Ground has high heat capacity and thermal inertia which absorbs $46 \%$ of the sun's energy and makes temperature fluctuation of the ground surface penetrate deeper into the ground at an exponential rate $[3,4]$. Therefore, a time lag occurs between the temperature fluctuations at the surface and in the ground. Thus, at sufficient depth, the ground temperature is constant and almost equal to the mean annual air temperature. Heat transfer analysis was performed in much of the twentieth-century research for utilizing 
constant ground temperature throughout the year. It was found that useful cooling and heating can be extracted in summer and winter respectively by means of underground heat exchangers. This method is an indirect way of utilizing the low underground temperature. Another method is direct contact in which part or all of a building has direct contact with the ground surface [5-9].

Underground heat exchangers have been called by different names such as buried pipe systems, underground air tunnels, ground heat exchangers, earth tube heat exchangers and earth air tunnels [10]. Throughout this paper, the term ground heat exchanger (GHE) is used for consistency of understanding. All over the world, the GHE is implemented in a variety of applications such as building thermal comfort, animal dwelling and agricultural greenhouses [11-14]. These applications are the most effective for passive energy sources from the ground which easily meet the heating and cooling requirement of buildings. The GHE is also used for district heating in some countries $[15,16]$. Performance of the GHE strongly depends on the air inlet temperature and the pipe wall temperature which in turn depends on the ground temperature variation. The influences of the inlet temperature and the pipe wall temperature on the GHE's performance have been reported since the 1980s [17, 18]. They applied a mathematical model and an experimental study on the GHE and the result showed good agreement between the mathematical model and experimental study. Cooling application of the GHE is normally implemented during summer and day time in European and arid regions as the ground temperature is lower than ambient air temperature [19].

\section{APPLICATION OF THE GHE}

There are two major applications of the GHE for cooling purposes as mentioned by [11]: 1) cooling of buildings for thermal comfort, and 2) cooling of agricultural greenhouses.

\section{Building Thermal Comfort}

Implementation of GHE for cooling a building is a kind of energy source resulting in energy saving and reduction of greenhouse gas emissions produced by fossil fuel. Energy saving in buildings is the aim of most countries [20-22]. The reduction of greenhouse gas emissions is a result of energy-saving implementation [23-25]. GHE for thermal comfort can reduce energy consumption [26]. Ground temperature has been investigated in the past few decades [19, 27], and has been used for passive space cooling in many countries [26, 28, 29]. The implementation of GHE for thermal comfort has been studied by many researchers. In early work [18] and [30] conducted mathematical analysis and field measurement of a GHE system for the cooling and heating of buildings. The system comprised a large main tunnel and a few subsidiary tunnels connected to a hospital complex in Delhi, India. The cross-sectional area of the tunnel varied from $0.91 \mathrm{~m} \times 0.91 \mathrm{~m}$ to $3.66 \mathrm{~m} \times 4.57 \mathrm{~m}$. The experiments were performed all year round to analyze cooling and heating performance. The cooling capacity of the tunnel was found to be considerably greater than its heating capacity: approximately $512 \mathrm{kWh}$ and $269 \mathrm{kWh}$ respectively.

Thanu et al. [31] analyzed thermal performance of a GHE connected to a farmhouse. The farmhouse had six main areas: three bedrooms, a living room, a dining room and a kitchen. The single-pass mode of GHE was implemented consisting of two rectangular tunnels measuring $60 \mathrm{~cm} \times 80 \mathrm{~cm}$ with a length of $76.5 \mathrm{~m}$. The tunnels were 
buried at a depth of $4 \mathrm{~m}$. Thermal performance of the GHE was analyzed in three seasons: summer, monsoon and winter. The best achievement of temperature reduction was recorded in summer at $14.8^{\circ} \mathrm{C}$ and the worst was in winter with $2^{\circ} \mathrm{C}$ of temperature increment. Performance of three GHEs at three different locations for mid-European office in service was analyzed by characterizing their efficiency [11]. Temperature behavior of the GHEs was described by plotting it over time and characteristic lines. The author also illustrated the energy gain and constructed a parametric model to provide general efficiency criteria. The highest primary energy saving was $88.6 \mathrm{~kW}$.

Al-Ajmi et al. [32] analyzed the potential of GHE implementation using TRNSYS-IISIBAT for buildings in the hot and arid climate of Kuwait. The simulation result showed that the GHE could provide a reduction of $1700 \mathrm{~W}$ in cooling with indoor temperature reduction of $2.8^{\circ} \mathrm{C}$. Givoni [33] conducted a test of cooling soil by two strategies; 1) covering the soil with a layer of gravel of about $12 \mathrm{~cm}$ and keeping the soil moist, and 2) keeping the moist soil constantly shaded. The author reported that a substantial cooling of the soil was achieved. Wu et al. [34] evaluated cooling capacity produced by a GHE implemented in Southern China. A daily cooling capacity up to $74.6 \mathrm{kWh}$ was obtained from a system with $60 \mathrm{~m}$ of pipe buried at a depth of $3.75 \mathrm{~m}$. Lee and Strand [35] developed a GHE module for implementation in EnergyPlus software. A parametric study was carried out to investigate the effect of pipe radius, pipe length, air flow rate, and pipe depth on the overall performance of the GHE. Cooling and heating potential were investigated and the performance was found to depend on climatic conditions and locations. The highest reduction in cooling load requirement was $8.8 \mathrm{kWh}$ with $52 \%$ of energy saving. Ascione et al. [36] analyzed the energy performance of an air-conditioned building combined with GHE in the Italian climate. They used dynamic building energy performance simulation codes for analyzing the system performance during both winter and summer. The authors reported that the highest primary energy saving for a 50 m length of GHE tube was about 14.2 $\mathrm{kWh} / \mathrm{m}^{2}$. The implementation of a GHE for buildings is feasible and economically acceptable with a simple payback of five to nine years.

\section{Agricultural Greenhouse Cooling}

An agricultural greenhouse is a crop cage with a transparent cover designed to create favorable and controlled conditions for cultivation of desired crops throughout the year. A greenhouse is essentially an enclosed structure which traps short wavelength solar radiation and stores long wavelength thermal radiation to create a favorable micro climate for higher productivity. During summer and even on clear days in winter, high solar radiation intensity increases the air temperature inside the cover to a very high level. To overcome this kind of problem, utilization of cooling technologies is essential. The GHE has great potential for greenhouse cooling because it can control humidity and lower the inside air temperature by up to $6^{\circ} \mathrm{C}$. Such systems have been tested and applied by many researchers worldwide and are able to serve as cooling systems for greenhouse application.

One such application was reported by [37]. The study was conducted in Argentina with a greenhouse measuring $43 \times 7.2 \mathrm{~m}^{2}$. The greenhouse was covered with a single PE sheet $150 \mu \mathrm{m}$ thick and the pipes were made of galvanized sheet iron buried at a depth of $1.2 \mathrm{~m}$. Santamouris et al. [38] described the design, construction and operation of a prototype $1000 \mathrm{~m}^{2}$ passive solar agricultural greenhouse by using several methods to increase heat gain such as water, latent heat material, rock bed and buried 
pipes. The researchers also discovered that the cooling potential of the GHE was very important. In the following year, they conducted a study on the performance of an earthair heat exchanger in cooling agricultural greenhouses and conserving energy. A parametric analysis was performed of a typical glass greenhouse to illustrate the effect of pipe length, pipe diameter, depth and air velocity on the performance of the system with the transient system simulation program (TRNSYS 1990). The simulation results were compared with their previous measured data and were found to be in very good agreement [39]. Wang and Liang [40] reported the performance of underground heat storage systems for greenhouse application by using a GHE. The system was designed to handle low ambient temperature during the nighttime which affected the crops. Heat inside the greenhouse in the daytime was absorbed by the GHE and transferred to the ground by means of convection and the heat was then stored in the ground. In the nighttime, heat in the ground was released by conduction to the greenhouse floor. This method was designed to provide a cooling effect in the daytime and a heating effect in the nighttime.

There are numerous reports from India on GHE use in greenhouses. The system has been used for both heating in winter and cooling in summer. The design and development of GHEs for cooling or heating in India began with the measurement of underground soil temperature in the arid zone of India by [41]. The detailed performance of the GHE system for greenhouse application is reported by [42]; a single-pass GHE is located in the arid area of Kutch, India. The system is made of $50 \mathrm{~m}$ long mild steel pipe with $10 \mathrm{~cm}$ nominal diameter and buried $3 \mathrm{~m}$ deep below the ground surface. There were three temperature measurement locations which are at the inlet, middle and exit of the pipe respectively with the air velocity of $11 \mathrm{~m} / \mathrm{s}$. Outlet temperature of $26.8^{\circ} \mathrm{C}$ was achieved at ambient temperature of $40.8^{\circ} \mathrm{C}$ for cooling test. The basic soil temperature at a depth of $3 \mathrm{~m}$ was measured as $26.6^{\circ} \mathrm{C}$. After the authors analyzed the single-pass GHE for agricultural greenhouses, they built a closed-loop GHE for the same purpose [43]. The system consisted of eight pipes arranged in two tiers. The first tier had four pipes buried at $3 \mathrm{~m}$ depth. The second also had four pipes buried at $2 \mathrm{~m}$ depth. Each pipe was $23 \mathrm{~m}$ long and $20 \mathrm{~cm}$ in nominal diameter. The system was able to reduce greenhouse temperature up to $7^{\circ} \mathrm{C}$ in summer compared with ambient temperature. Few works from the authors until year 2004 have been summarized in [44], who described the application of GHEs in Gujarat which consider as arid area in India is significant either for cooling or heating for greenhouse and animal dwelling application.

The thermal modeling of a greenhouse was developed at the India Institute of Technology by [45-47]. The greenhouse was integrated with a GHE. The important parameters in this work were: greenhouse temperature working with and without GHE, heating and cooling potential of GHE and thermal load leveling. The thermal modeling was validated by experiment and it exhibited fair agreement. Two other research papers [48] and [49] give strong support to the application of GHEs for agricultural greenhouse in arid areas of India. Latter [50] reported environmental control in greenhouse and animal houses with GHE. The system applied irrigation and supplementary evaporative cooling in a semi-arid area of north-west India. Two modes of operation were investigated: cooling and heating. The system had a significant effect on crop growing requirement and tomatoes showed good productivity. 


\section{UNDERGROUND TEMPERATURE VARIATION}

The implementation of GHEs requires knowledge of underground temperature variation, thermal behavior of the soil and soil properties. Obviously, the underground temperature remains almost constant at a certain depth throughout the year. It is higher than ambient air temperature in winter and lower in summer [51]. This means the ground has significant potential for cooling and heating all year round. Since this paper is intended to discuss the cooling application of GHE, discussion will be focused on cooling potential of the ground described in the available literature. Ground is classified by three different zones according to depth; 1) surface zone that reaches a depth of about $1 \mathrm{~m}, 2$ ) shallow zone that extends from a depth of about $1 \mathrm{~m}$ to $8 \mathrm{~m}$, and 3) deep zone with a depth of 8 to $20 \mathrm{~m}$. In the shallow zone, the ground temperature distributions depend mainly on the seasonal weather condition. Meanwhile, in the deep zone the ground temperature is practically constant. The ground temperature varies according to latitude, weather conditions, time of year, altitude, landscaping, shading, neighboring buildings, earth surface conditions, soil properties, rainfall and other factors $[19,52]$. Florides and Kalogirou [10] determined underground temperature variation at various depths during summer and winter. The temperature was nearly constant below a depth of $5 \mathrm{~m}$ all year round. Chow et al. [51] analyzed the soil temperature in Hong Kong based on available data from 1995 until 2009. The analysis was conducted at different depths from the ground surface up to $3 \mathrm{~m}$. Different depths showed different temperature variations; $3 \mathrm{~m}$ presented small temperature amplitude compared with other depths. Pfafferot [11] and Pfafferot et al. [53] presented average annual temperature profile at depths of $1 \mathrm{~m}, 2 \mathrm{~m}, 4 \mathrm{~m}$ and $8 \mathrm{~m}$. Their findings showed that the temperature at depths of 4 and $8 \mathrm{~m}$ was consistent throughout the year in the range of 9 to $13^{\circ} \mathrm{C}$. Ascione et al. [36] conducted a study of underground temperature as part of research on implementing a GHE in an air-conditioned building during winter and summer. They found that configurations for the GHE at a depth of $3 \mathrm{~m}$ for summer and winter showed a good compromise between energy performance and cost of excavation.

Significant heating and cooling potential of soil was investigated in India by [41]. Letter [54] measured and simulated the soil temperature regime up to $3 \mathrm{~m}$ depth with $1 \mathrm{~m}$ intervals. The temperature amplitude was attenuated with depth: $2.8^{\circ} \mathrm{C}$ at $3 \mathrm{~m}$ compared with $4.6^{\circ} \mathrm{C}$ at $1 \mathrm{~m}$. The findings were applied to GHEs for buildings and greenhouses by [42, 43, 50]. Al-Ajmi et al. [32] conducted a measurement and simulation study of soil temperature for hot and arid climates. The temperature was attenuated from $13.3^{\circ} \mathrm{C}$ at the ground surface to $3.95^{\circ} \mathrm{C}$ at a depth of $4 \mathrm{~m}$. Derbel et al. [55] investigated the soil temperature variation for different depths and types of soil using neural network predictions. Four types of soil and four different depths were considered. The results showed that different thermal diffusivity produces different temperature variation at the same depth. Yusof et al. [56] analyzed ground temperature in Malaysia based on mathematical model which summarized that the constant temperature occurred at depth of $6 \mathrm{~m}$ with $27^{\circ} \mathrm{C}$ of temperature. Significant cooling for GHE purpose can be produced from the depth of $2.4 \mathrm{~m}$ and deeper.

\section{DESIGN AND PERFORMANCE}

The GHE is a simple heat exchanger system which requires a pipe or several pipes buried at a certain depth below the ground surface to transfer heat from the air to the ground. One end of the pipe acts as an inlet for the outdoor ambient air and the other 
end acts as an outlet which releases the air into the conditioned spaces. Outdoor ambient air is drawn into the pipe through the inlet end and travels along the pipe which exchanging the heat with the pipe walls. The pipe is contacting with the surrounding underground environment makes the temperature of the pipe surface is almost or similar as temperature of the ground at particular depth. This temperature is usually lower than ambient temperature. In this way, heat is transferred to the surrounding soil by means of convection in the air tunnel to the pipe wall and conduction from the pipe wall to the surrounding soil.

The GHE can be designed with both an open-loop and a closed-loop system as shown by Figure 1 and Figure 2 [26, 29]. These systems can be single pipes or several pipes buried below the ground surface. The open-loop design of the GHE has been reported by [29]. The design is simple and there is no complex equipment attached. The closed-loop multi-pipe GHE was reported by [43] for a hot and arid area of India for agricultural application. The system consisted of two tiers with four parallel pipes $20 \mathrm{~cm}$ in diameter and $20 \mathrm{~m}$ long, each placed at depths of $2 \mathrm{~m}$ and $3 \mathrm{~m}$ respectively. Paepe and Jenssons [28] designed a GHE based on the definition of heat exchanger effectiveness. Several parameters were studied such as pipe diameter, pipe length, and number of pipes. They also established design maps of the GHE from which proper selection of the design parameters could be made. Other design parameters of the GHE are shown in Table 1.

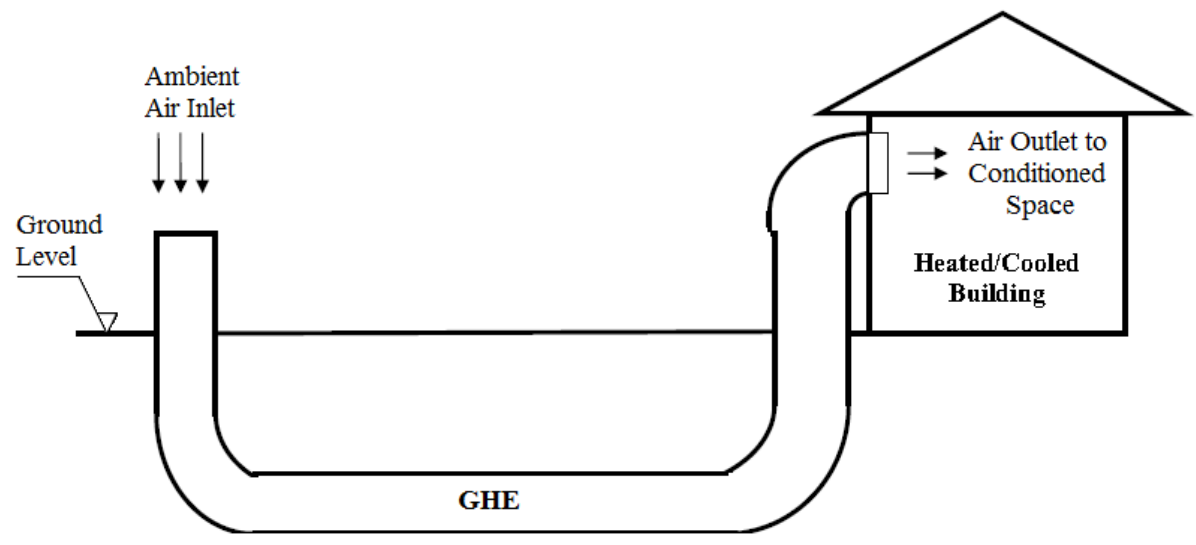

Figure 1. Schematic of open loop GHE.

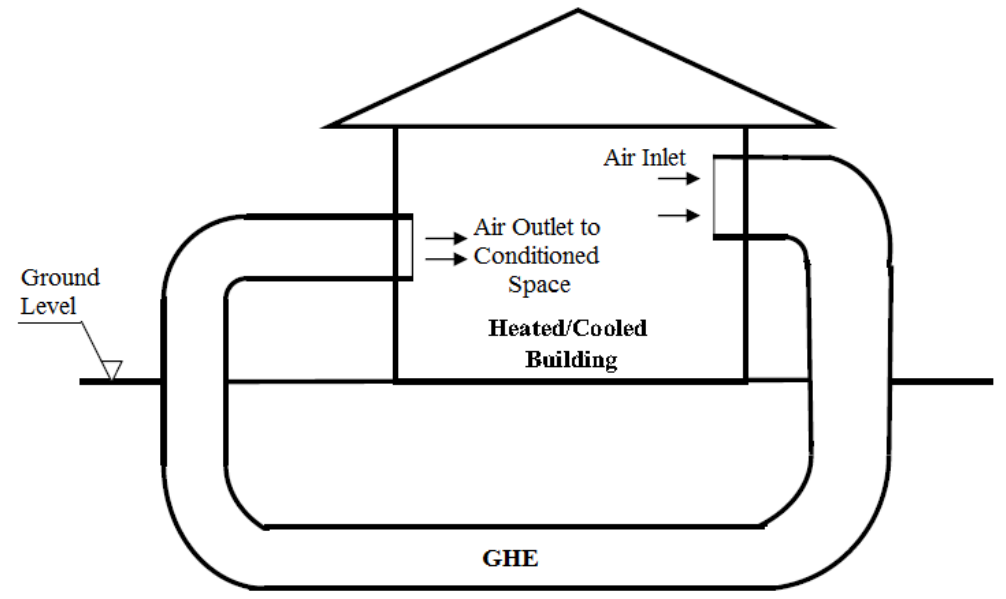

Figure 2. Schematic of closed-loop GHE. 
Table 1. Design parameter of the GHE.

\begin{tabular}{|c|c|c|c|c|c|c|}
\hline $\begin{array}{l}\text { References and study } \\
\text { approach }\end{array}$ & $\begin{array}{l}\text { Depth, z } \\
\quad(\mathrm{m})\end{array}$ & $\begin{array}{c}\text { Pipe } \\
\text { radius, } R, \\
(\mathrm{~cm})\end{array}$ & $\begin{array}{c}\text { Pipe } \\
\text { length, } L \\
\text { (m) }\end{array}$ & $\begin{array}{l}\text { Velocity, V } \\
\quad(\mathrm{m} / \mathrm{s})\end{array}$ & $\begin{array}{l}\text { Flowrate, } M \\
\quad(\mathrm{~kg} / \mathrm{s})\end{array}$ & $\begin{array}{c}\text { Thermal } \\
\text { Conductivity } \\
\text { (W/m.K) }\end{array}$ \\
\hline $\begin{array}{l}{[17] \text { - Numerical and }} \\
\text { experimental. }\end{array}$ & 2.13 & 15 & 24.7 & 1.5 & 0.1272 & $k_{s}=1.16$ \\
\hline [31] - Experimental & 4 & 48 & 76.5 & 6.7 & 5.82 & $k_{p}=0.18$ \\
\hline [32] - Numerical & $\begin{array}{l}1.7 \text { and } \\
2.13\end{array}$ & 20 and 15 & Up to 24.7 & Up to 10.5 & $\begin{array}{l}\text { Up to } \\
1.5834\end{array}$ & $k_{s}=1.16$ \\
\hline [35] - Numerical & 2.13 & 15 & 24.7 & 1.5 & 0.1272 & $k_{s}=1.16$ \\
\hline [36] - Numerical & 3 & 16.5 & 50 & 7.7 & 0.7903 & $\begin{array}{c}k_{p}=0.16 \\
k_{s}=1.0-1.9\end{array}$ \\
\hline [57] - Experimental & 1.7 & 20 & 13 & $0.5-10.5$ & $\begin{array}{c}0.0745- \\
1.5834\end{array}$ & 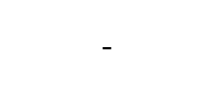 \\
\hline [58] - Numerical & 4 & 5 & 30 & 6 & 0.0565 & $\begin{array}{c}k_{p}=0.18 \\
k_{s}=1.16\end{array}$ \\
\hline [59] - Experimental & 3 & 28 & 47 & 3.1 & 1.7 & $k_{s}=2.85$ \\
\hline [60] - Experimental & 3.7 & 5 & 60 & 5 & - & $\begin{array}{c}k_{s}=0.52 \\
k_{p}=0.16\end{array}$ \\
\hline
\end{tabular}

The thermal and energy performances of a GHE system are influenced by several factors such as pipe specification, pipe material, circulating fan, soil thermal properties and moisture content [26, 29]. Previously, [61] reported that the most costeffective combination of pipes for cooling capacity in the Jodhpur (India) climate was $1920 \mathrm{kWh} / \mathrm{m}^{2}$ with $5 \mathrm{~cm}$ radius, $12.5 \mathrm{~m}$ length, $2400 \mathrm{~m}^{3} / \mathrm{h}$ of volume flowrate and 16 pipes. Goswami and Dhaliwal [17] achieved a temperature reduction from $32.2^{\circ} \mathrm{C}$ to $23.9^{\circ} \mathrm{C}$. The mass flowrate $(\dot{m})$ recorded was $390 \mathrm{~m}^{3} / \mathrm{h}$. The diameter of the pipe was $0.3 \mathrm{~m}$ and its length was $25 \mathrm{~m}$. A large GHE for a farmhouse achieved temperature reduction of $8.3^{\circ} \mathrm{C}$ (from 36.1 to $27.8^{\circ} \mathrm{C}$ ) [31]. The highest reduction was $14.8^{\circ} \mathrm{C}$ in the daytime.

Ozgener and Ozgener [62] obtained the maximum cooling power of $11.54 \mathrm{~kW}$ for a GHE with a $0.28 \mathrm{~m}$ radius, $47 \mathrm{~m}$ length and volume air flowrate of $5300 \mathrm{~m}^{3} / \mathrm{h}$. Bansal et al., [63] developed a transient and implicit model based on computational fluid dynamics to predict the thermal performance and cooling capacity of a GHE system in Western India. The system consisted of a $23.42 \mathrm{~m}$ long pipe with velocity of 2 $-5 \mathrm{~m} / \mathrm{s}$, providing cooling in the range of 8.0 to $12.7^{\circ} \mathrm{C}$. Investigations on steel and PVC pipes have also been performed and it has been found that there is no significant effect of the pipe material [63]. Computer simulation and experimental investigations of thermal performance of GHE were conducted by [64]. The system reduced cooling loads and significantly reduced the room air temperature during summer seasons. The authors used EnergyPlus software to estimate the cooling potential of the GHE in residential buildings for different climate conditions. The cooling load reduced significantly by $595 \mathrm{kWh}$ and temperature reduction was $1.9^{\circ} \mathrm{C}$. An experimental study of GHE performance in Burkina Faso was conducted by [65]. The system was tested at the hottest time of the day $\left(39^{\circ} \mathrm{C}\right)$. The system was $25 \mathrm{~m}$ long, $125 \mathrm{~mm}$ in diameter, buried at $1.5 \mathrm{~m}$ depth and had a volume flowrate of $95 \mathrm{~m}^{3} / \mathrm{h}$. It was able to cool the ambient air by $7.6^{\circ} \mathrm{C}$ from the outside. A large GHE was reported by [66] with $1000 \mathrm{~m}$ tunnel length and $4 \mathrm{~m}$ radius; air velocity was recorded as $1 \mathrm{~m} / \mathrm{s}$. The average and maximum temperature drop of the air stream were 2.35 and $8.93^{\circ} \mathrm{C}$ respectively. 


\section{MALAYSIAN CLIMATE AND BENEFIT OF GHE IMPLEMENTATION}

Malaysia is located between $1^{\circ}$ and $7^{\circ}$ latitude north and $100^{\circ}$ and $120^{\circ}$ longitude east. The lowest temperature is $21^{\circ} \mathrm{C}$ and the highest temperature is $33^{\circ} \mathrm{C}$. The average annual temperature is $27^{\circ} \mathrm{C}$ and the average daytime temperature is about $31^{\circ} \mathrm{C}$. However, temperature of 23 to $26^{\circ} \mathrm{C}$ is commonly used for human comfort in commercial buildings (MS 1525). The demand for electricity for cooling is increasing and leads to the utilization of renewable energy and sources of thermal storage [67]. In order to investigate the potential of GHEs for the Malaysian climate, analysis of local ambient temperature is essential. The local ambient temperature was obtained from Weatherspark for three consecutive years from 2010 until 2012. Statistical analysis of ambient temperature was obtained from Weatherspark for Station 34038, Sultan Haji Ahmad Shah Airport, Kuantan. Figure 3 shows ambient temperature for the three consecutive years. Hourly temperature was obtained and the mean daily temperature was $26.9^{\circ} \mathrm{C}$. The lowest and highest temperatures were $22.7^{\circ} \mathrm{C}$ and $34^{\circ} \mathrm{C}$ respectively. The amplitude of surface temperature was $5.7^{\circ} \mathrm{C}$ and the lowest temperature was taken on day 365 on the basis of daily average temperature as shown by Figure 4 .

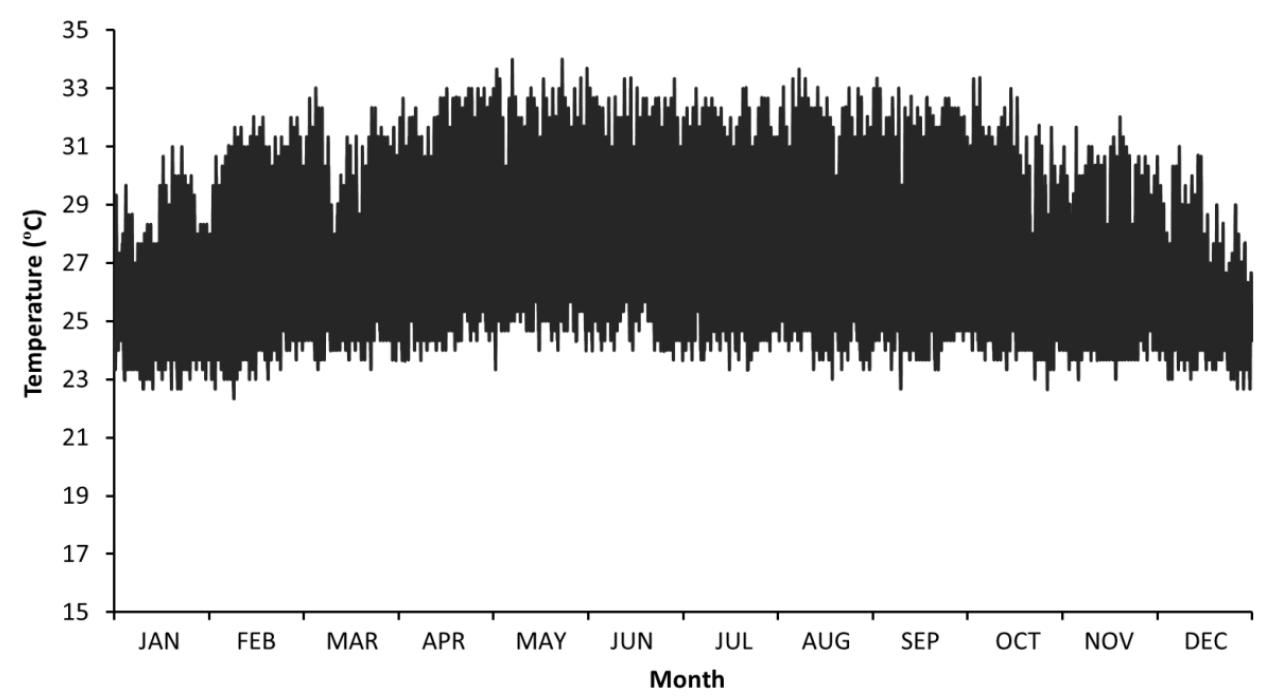

Figure 3. Ambient temperature for 2010 until 2012.

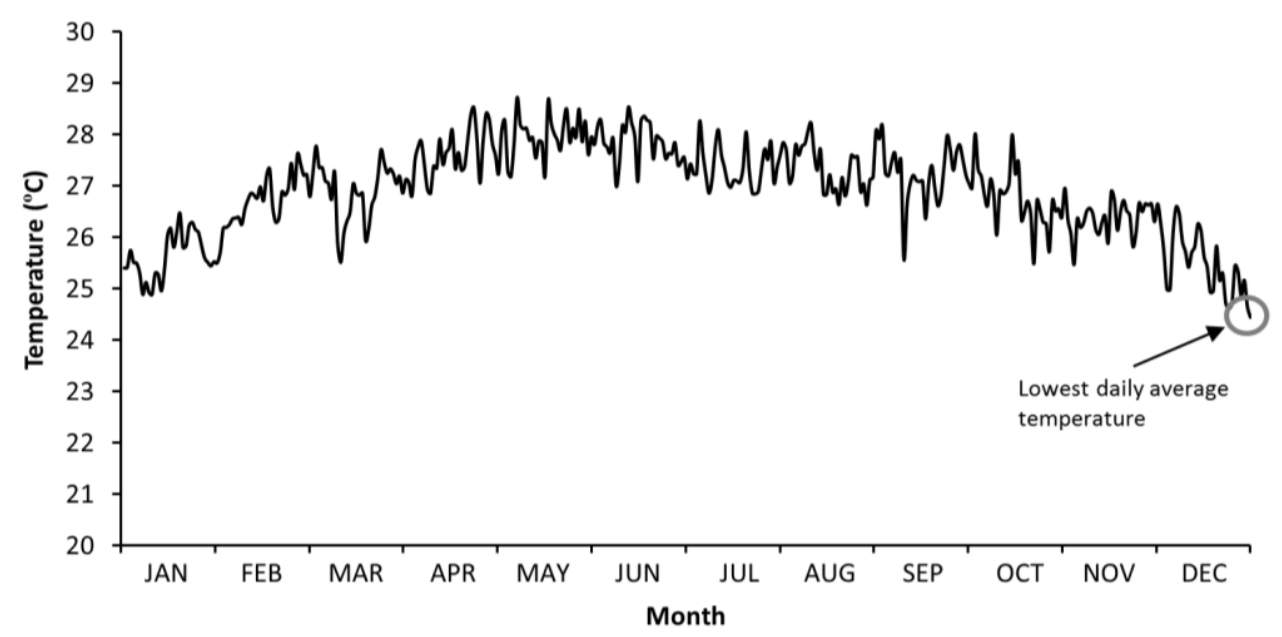

Figure 4. Average daily temperature. 
The underground temperature at certain depths below the ground is constant throughout the year $[59,68,69]$. The magnitude of temperature at this point is almost equal to the local annual average ambient temperature. In the case of the Malaysian climate, the annual average ambient temperature is $26.9^{\circ} \mathrm{C}$ and the ground temperature is assumed to be the same. Therefore, the cooling potential from the ground can be analyzed by establishing daily temperature graph and ground temperature as shown in Figure 5. There were five daily temperatures at different dates. The gray area indicates potential of cooling that can be supplied from the ground. The highest potential of cooling occurred during the hot season from March to September. The sample of temperature pattern in the dry season is presented by graph lines on April 1 and July 1 in Figure 5. The graph clearly shows that there is huge potential for cooling by passive means, which can be supplied by the GHE from 09.00 until 23.00 on April 1. Then, the cooling potential reduces as the rainy season approaches. The lowest cooling illustrated by graph lines is on December 1 (in the rainy season).

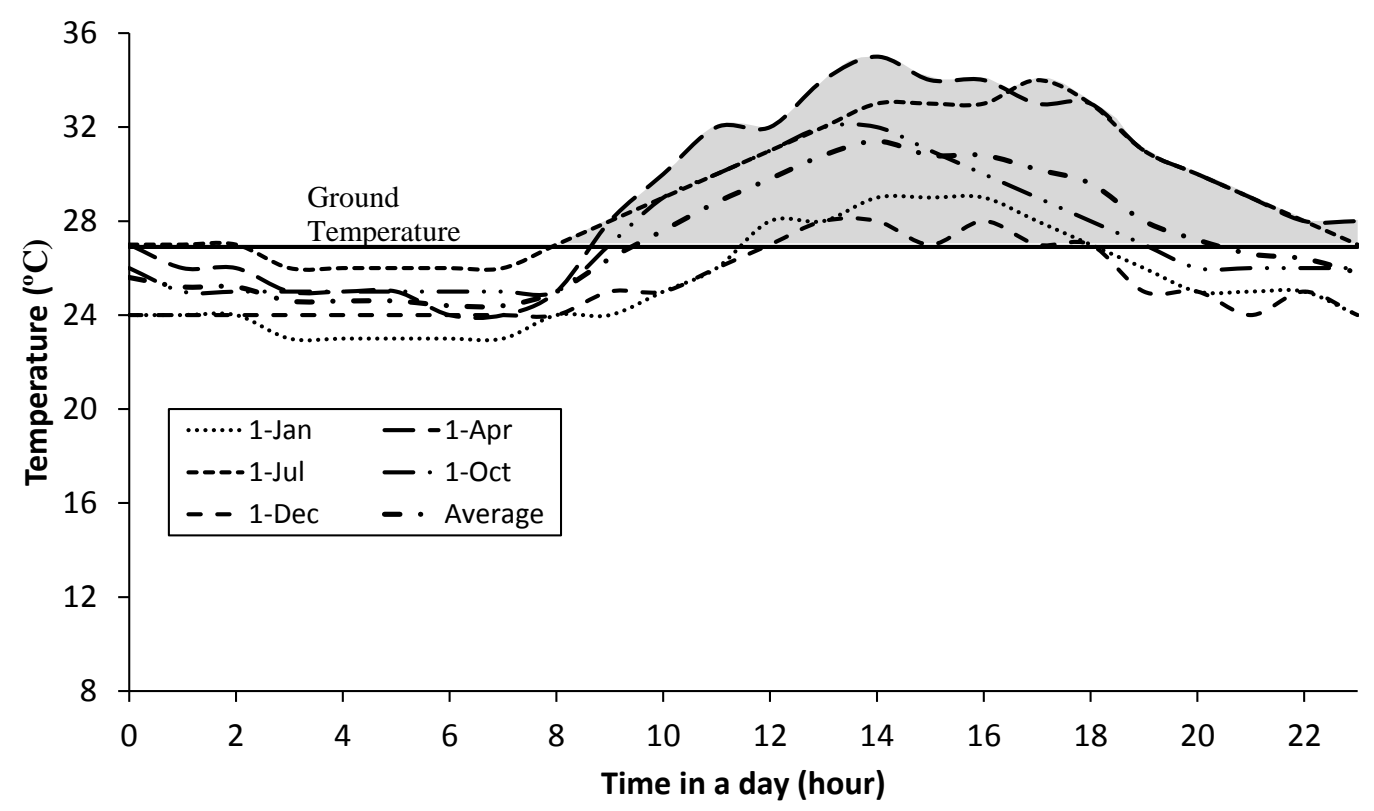

Figure 5. Daily temperature patterns at different date.

For the cooling load below the ground temperature line, the GHE is unable to provide the cooling effect. This is because the ground temperature is constant at $26.9^{\circ} \mathrm{C}$ at certain depths. In order to achieve room temperature at $25^{\circ} \mathrm{C}$ as suggested by Malaysian Standard MS 1525:2007, active cooling is necessary such as a split-unit airconditioning system. The potential energy reduction through implementing GHE is illustrated in gray in Figure 5; it is the difference between ambient temperature and ground temperature. Al-Ajmi et al. [32] reported indoor temperature reduction of $2.8^{\circ} \mathrm{C}$ for a free-running GHE without an active air-conditioning system. During the hot dry season, they obtained a cooling capacity reduction of $30.1 \%$. The annual average ground temperature in the study was $27^{\circ} \mathrm{C}$, which is very close to Malaysia's $26.9^{\circ} \mathrm{C}$. Therefore, for Malaysia, it is expected that the cooling capacity reduction would be substantial, given the report by [32]. Since the ambient temperature varies throughout the year, the energy required to take down the room temperature also varies in accordance with the ambient temperature variation. This is also reflected in the specific energy performance as reported by [53]. The specific energy performance can achieve 
up to $50 \mathrm{~W} / \mathrm{m}^{2}$ for the ambient temperature of $32^{\circ} \mathrm{C}$ and it can increase up to $70 \mathrm{~W} / \mathrm{m}^{2}$ for the ambient temperature of $34^{\circ} \mathrm{C}$. Different ambient temperature results in different specific energy performance, which depends on ground temperature.

\section{CONCLUSIONS}

The GHE is one of the methods that can be used for reducing energy consumed in buildings and agricultural greenhouses. Both heating and cooling requirement can be supply by the GHE. Application of GHE for cooling purpose has been identified that it can give a better performance. Thermal performance of the GHE depends on several main factors such as ground temperature variation, design and specification of the GHE pipe. Each of the main factor is future depends on several sub-factors. Geographical sub-factor which related to the average ambient temperature gives a huge effect to the ground temperature variation. The magnitude of constant temperature variation occurred with the same as the local average ambient temperature. The local average ambient temperature in this study obtained as $26.9^{\circ} \mathrm{C}$, therefore the $\mathrm{GHE}$ is able to produce significant passive cooling for the Malaysian climate since the daytime temperature can reach up to $34^{\circ} \mathrm{C}$. However, the implementation of $\mathrm{GHE}$ in Malaysia requires detail ground temperature study at different depth. The ground temperature study in Malaysia should be conducted at different location nationwide using mathematical model and measurement methods. Combination of GHE's system design and pipe specification for optimum performance also become a great focus for future study of GHE implementation in Malaysia in achieving energy saving and greenhouse gas emission produce by fossil fuel.

\section{ACKNOWLEDGEMENTS}

The authors would like to thank the Faculty of Mechanical Engineering for providing the research facilities and Universiti Malaysia Pahang for financial support under RDU130333

\section{REFERENCES}

[1] Jaisankar S, Ananth J, Thulasi S, Jayasuthakar ST, Sheeba KN. A comprehensive review on solar water heaters. Renewable and Sustainable Energy Reviews. 2011;15:3045-50.

[2] Mahendran M, Lee GC, Shahrani A, Bakar RA, Kadirgama K, Amir AR, et al. Diurnal pattern and estimation of global solar radiation in East Coast Malaysia. International Journal of Automotive and Mechanical Engineering. 2013;8:14.

[3] Mazarrón FR, Cid-Falceto J, Cañas I. Ground Thermal Inertia for Energy Efficient Building Design: A Case Study on Food Industry. Energies. 2012;5:227-42.

[4] Ministry of Natural Resources Canada. Ground-source heat pump project analysis. 3rd ed. Canada: RETScreen Engineering \& Cases; 2005.

[5] Mihalakakou G, Santamouris M, Asimakopoulos D. Modelling the earth temperature using multiyear measurements. Energy and Buildings. 1992;19:1-9.

[6] Mihalakakou G, Lewis JO, Santamouris M. The influence of different ground covers on the heating potential of earth-to-air heat exchangers. Renewable Energy. 1996;7:33-46. 
[7] Bhuiyan AA, Amin MR, Karim R, Sadrul Islam AKM. Plate fin and tube heat exchanger modeling: Effects of performance parameters for turbulent flow regime. International Journal of Automotive and Mechanical Engineering. 2014;9:1768-81.

[8] Tahseen TA, Rahman MM, Ishak M. An experimental study of air flow and heat transfer over in-line flat tube bank. International Journal of Automotive and Mechanical Engineering. 2014;9:1487-500.

[9] Tahseen TA, Rahman MM, Ishak M. Heat Transfer and Pressure Drop Prediction in an in-Line Flat Tube Bundle by Radial Basis Function Network. International Journal of Automotive and Mechanical Engineering. 2014;10:2003-15.

[10] Florides G, Kalogirou S. Ground heat exchangers-A review of systems, models and applications. Renewable Energy. 2007;32:2461-78.

[11] Pfafferott J. Evaluation of earth-to-air heat exchangers with a standardised method to calculate energy efficiency. Energy and Buildings. 2003;35:971-83.

[12] Rao GS, Sharma KV, Chary SP, Bakar RA, Rahman MM, Kadirgama K, et al. Experimental study on heat transfer coefficient and friction factor of $\mathrm{Al}_{2} \mathrm{O}_{3}$ nanofluid in a packed bed column. Journal of Mechanical Engineering and Sciences. 2011;1:1-15.

[13] Syam Sundar L, Sharma KV. An experimental study on heat transfer and friction factor of $\mathrm{Al}_{2} \mathrm{O}_{3}$ nanofluid. Journal of Mechanical Engineering and Sciences. 2011;1:99-112.

[14] Tahseen TA, Ishak M, Rahman MM. A numerical study of forced convection heat transfer over a series of flat tubes between parallel plates. Journal of Mechanical Engineering and Sciences. 2012;3:271-80.

[15] Perpar M, Rek Z, Bajric S, Zun I. Soil thermal conductivity prediction for district heating pre-insulated pipeline in operation. Energy. 2012;44:197-210.

[16] Dalla Rosa A, Li H, Svendsen S. Method for optimal design of pipes for lowenergy district heating, with focus on heat losses. Energy. 2011;36:2407-18.

[17] Goswami DY, Dhaliwal AS. Heat transfer analysis in environmental control using an underground air tunnel. Journal of Solar Energy Engineering. 1985;107:141-5.

[18] Sodha MS, Sharma AK, Singh SP, Bansal NK, Kumar A. Evaluation of an earth-air tunnel system for cooling/heating of a hospital complex. Building and Environment. 1985;20:115-22.

[19] Kasuda T, Archenbach PR. Earth Temperature and thermal diffusivity at selected station in the United States. ASHRAE Transaction. 1965;71:15.

[20] Ballarini I, Corgnati SP, Corrado V. Use of reference buildings to assess the energy saving potentials of the residential building stock: The experience of TABULA project. Energy Policy. 2014;68:273-84.

[21] Ye H, Long L, Zhang H, Gao Y. The energy saving index and the performance evaluation of thermochromic windows in passive buildings. Renewable Energy. 2014;66:215-21.

[22] Katunsky D, Korjenic A, Katunska J, Lopusniak M, Korjenic S, Doroudiani S. Analysis of thermal energy demand and saving in industrial buildings: A case study in Slovakia. Building and Environment. 2013;67:138-46.

[23] Friedler F. Process integration, modelling and optimisation for energy saving and pollution reduction. Applied Thermal Engineering. 2010;30:2270-80. 
[24] Corsten M, Worrell E, Rouw M, van Duin A. The potential contribution of sustainable waste management to energy use and greenhouse gas emission reduction in the Netherlands. Resources, Conservation and Recycling. 2013;77:13-21.

[25] Hwang JJ. Policy review of greenhouse gas emission reduction in Taiwan. Renewable and Sustainable Energy Reviews. 2011;15:1392-402.

[26] Bisoniya TS, Kumar A, Baredar P. Experimental and analytical studies of earthair heat exchanger (EAHE) systems in India: A review. Renewable and Sustainable Energy Reviews. 2013;19:238-46.

[27] Penrod EB, Elliott JM, Brown WK. Soil Temperature Variation (1952-1956) at Lexington, Kentucky. Soil Science. 1960;90:275-83.

[28] De Paepe M, Janssens A. Thermo-hydraulic design of earth-air heat exchangers. Energy and Buildings. 2003;35:389-97.

[29] Ozgener L. A review on the experimental and analytical analysis of earth to air heat exchanger (EAHE) systems in Turkey. Renewable and Sustainable Energy Reviews. 2011;15:4483-90.

[30] Bansal NK, Sodha MS. An earth-air tunnel system for cooling buildings. Tunnelling and Underground Space Technology incorporating Trenchless. 1986;1(2):177-82.

[31] Thanu NM, Sawhney RL, Khare RN, Buddhi D. An experimental study of the thermal performance of an earth-air-pipe system in single pass mode. Solar Energy. 2001;71:353-64.

[32] Al-Ajmi F, Loveday DL, Hanby VI. The cooling potential of earth-air heat exchangers for domestic buildings in a desert climate. Building and Environment. 2006;41:235-44.

[33] Givoni B. Cooled soil as a cooling source for buildings. Solar Energy. 2007;81:316-28.

[34] Wu H, Wang S, Zhu D. Modelling and evaluation of cooling capacity of earthair-pipe systems. Energy Conversion and Management. 2007;48:1462-71.

[35] Lee KH, Strand RK. The cooling and heating potential of an earth tube system in buildings. Energy and Buildings. 2008;40:486-94.

[36] Ascione F, Bellia L, Minichiello F. Earth-to-air heat exchangers for Italian climates. Renewable Energy. 2011;36:2177-88.

[37] Levit HJ, Gaspar R, Piacentini RD. Simulation of greenhouse microclimate produced by earth tube heat exchangers. Agricultural and Forest Meteorology. 1989;47:31-47.

[38] Santamouris M, Argiriou A, Vallindras M. Design and operation of a low energy consumption passive solar agricultural greenhouse. Solar Energy. 1994;52:3718 .

[39] Santamouris M, Mihalakakou G, Balaras CA, Argiriou A, Asimakopoulos D, Vallindras M. Use of buried pipes for energy conservation in cooling of agricultural greenhouses. Solar Energy. 1995;55:111-24.

[40] Wang YW, Liang XF. Performance of underground heat storage system in a double-film-covered greenhouse. J Zhejiang Univ - Sci B. 2006;7:279-82.

[41] Krishnan A, Rao GGSN. Soil temperature regime in the arid zone of India. Arch Met Geoph Biokl B. 1979;27:15-22.

[42] Sharan G, Jadhav R. Performance of single pass earth tube heat exchanger: An experimental study. Journal of Agricultural Engineering. 2003;40:8. 
[43] Sharan G, Prakash H, Jadhav R. Performance of greenhouse coupled to earthtube-heat-exchanger in closed-loop mode 2004.

[44] Sharan G. Development and Some applications of earth tube heat exchanger in Gujarat. Nanubhai Amin Memorial Lecture at Electrical Research and Development Association, Vadodara; 2004.

[45] Ghosal MK, Tiwari GN. Modeling and parametric studies for thermal performance of an earth to air heat exchanger integrated with a greenhouse. Energy Conversion and Management. 2006;47:1779-98.

[46] Ghosal MK, Tiwari GN, Das DK, Pandey KP. Modeling and comparative thermal performance of ground air collector and earth air heat exchanger for heating of greenhouse. Energy and Buildings. 2005;37:613-21.

[47] Ghosal MK, Tiwari GN, Srivastava NSL. Thermal modeling of a greenhouse with an integrated earth to air heat exchanger: an experimental validation. Energy and Buildings. 2004;36:219-27.

[48] Sharan G, Jethva K. Cropping in arid area greenhouse 2006.

[49] Sharan G. Cropping in arid area greenhouse. 2007.

[50] Sharan G, Madhavan T. Environmental Control in Greenhouse and Animal Houses with Earth-Tube-Heat-Exchangers in Hot Semi-arid North-West India 2010.

[51] Chow TT, Long H, Mok HY, Li KW. Estimation of soil temperature profile in Hong Kong from climatic variables. Energy and Buildings. 2011;43:3568-75.

[52] Argiriuou A. Ground Cooling In: Santamouris M, Asimakopoulos D, editors. Passive cooling of buildings. London: James \& James; 2001. p. 360-401.

[53] Pfafferott J, Walker-Hertkorn S, Sanner B. Ground cooling: Recent Progress. In: Santamouris M, editor. Advances in Passive Cooling. London: EarthScan; 2007. p. 190-227.

[54] Sharan G, Jadhav R. Soil temperature regime at Ahmedabad. Journal of Agricultural Engineering. 2002;39.

[55] Derbel HBJ, Kessentini I, Konoun O. Investigation of the underground temperature using neural network. IEEE 5th International Multi-Conference on System, Signals and Devices 2008. Amman, Jordan.2008.

[56] Yusof TM, Anuar S, Ibrahim H. Numerical investigation of ground cooling potential for malaysia climate. International Journal of Automotive and Mechanical Engineering. 2014;10:2081-90.

[57] Shingari BK. Earth tube heat exchanger. Poultry International. 1995;34:92-7.

[58] Ben Jmaa Derbel H, Kanoun O. Investigation of the ground thermal potential in tunisia focused towards heating and cooling applications. Applied Thermal Engineering. 2010;30:1091-100.

[59] Ozgener O, Ozgener L, Tester JW. A practical approach to predict soil temperature variations for geothermal (ground) heat exchangers applications. International Journal of Heat and Mass Transfer. 2013;62:473-80.

[60] Misra R, Bansal V, Agrawal GD, Mathur J, Aseri TK. CFD analysis based parametric study of derating factor for Earth Air Tunnel Heat Exchanger. Applied Energy. 2013;103:266-77.

[61] Sodha MS, Buddhi D, Sawhney RL. Optimization of pipe parameters of an underground air pipe cooling system. Energy Conversion and Management. 1993;34:465-70. 
[62] Ozgener O, Ozgener L. Exergoeconomic analysis of an underground air tunnel system for greenhouse cooling system. International Journal of Refrigeration. 2010;33:995-1005.

[63] Bansal V, Misra R, Agrawal GD, Mathur J. Performance analysis of earth-pipeair heat exchanger for summer cooling. Energy and Buildings. 2010;42:645-8.

[64] Zukowski M, Sadowska B, W S. Assessment of the cooling potential of an earth-tube heat exchanger in residential buildings. The 8th International Conference of Environmental Engineering. Lithuania2011. p. 830-4.

[65] Woodson T, Coulibaly Y, ES T. Earth-air heat exchangers for passive air conditioning: Case study Burkina Faso. Journal of Construction in Developing Countries. 2012;17:12.

[66] Liu X, Xiao Y, Inthavong K, Tu J. A fast and simple numerical model for a deeply buried underground tunnel in heating and cooling applications. Applied Thermal Engineering. 2014;62:545-52.

[67] Shekarchian M, Moghavvemi M, Motasemi F, Zarifi F, Mahlia TMI. Energy and fuel consumption forecast by retrofitting absorption cooling in Malaysia from 2012 to 2025. Renewable and Sustainable Energy Reviews. 2012;16:6128-41.

[68] Cui W, Liao Q, Chang G, Chen G, Peng Q, Jen TC. Measurement and Prediction of Undisturbed Underground Temperature Distribution. Proceeding of the ASME 2011 International Mechanical Engineering Congress \& Exposition, USA. 2011; 1-6.

[69] Tsilingiridis G, Papakostas K. Investigating the relationship between air and ground temperature variations in shallow depths in northern Greece. Energy. 2014;73:1007-16. 